\title{
Inflation and Personal Saving: An Update
}

\author{
CLAUDIA R. CAMPBELL and JEAN M. LOVATI
}

ROM 1965 to 1974 , a decade of rapid inflation, households saved relatively more of their current income than they had in the previous decade of generally stable prices. Following the 1974 recession, however, the saving response of U.S. households to inflation appeared to undergo a major change. Despite the higher average rates of inflation from 197578 , the proportion of current income saved fell below that of the previous decade (Table 1 ).

Earlier studies of intlation and household saving generally concluded that U.S. households respond to price level increases by cutting back on borrowing and spending, thereby increasing their saving., ${ }^{1}$ Most of these studies encompass the period prior to 1975 , before saving rates plunged to post-World War II lows. If the positive relationship between saving and inflation no longer holds, a rising rate of inflation in the future is no guarantee of higher average rates of household saving. This development could have an adverse effect on future economic growth since lower average rates of household saving tend to restrict the future supply of funds used for investment in plant and equipment.

This paper updates earlier investigations of the relationship between inflation and saving to include the years, 1975 through 1978. In particular, it examines the long-rum saving response to inflation in order to determine whether the observed impact of inflation on saving is merely a temporary phenomenon.

\footnotetext{
1Recent work on this subject indicates that the positive response of saving to inllation is partially the result of uncertainty created by high and variable rates of inflation. See Paul Wachtel, "Inflation, Uncertainty and Saving Behavior Since the Mid-1950's" Explorations in Economic Research (Fall 1977), pp. 558-78. Coupled with uncertainty, household saving has been affected by the failure of corporate stocks to provide an adequate hedge against inflation. This is discussed in Philip Cagan and Robert Lipsey, The Financial Effects of Inflation, (Cambridge, Mass.: Ballinger Publishing Company, 1978). Another study suggests that households downgrade the quality of their purchases in response to a rise in the rate of price increases, producing the observed positive saving response to inflation. See Susan Burch and Diane Werneke, "The Stock of Consumer Durables, Inflation and Personal Saving Decisions, ${ }^{3 \pi}$ The Review of Economics and Statisties (May 1975), pp. $141-54$,
}

The long-run effect of inflation on household saving was estimated previously in a 1977 study by Paul Wachtel. Wachtel found that the uncertainty generated by inflation helped to explain the persistent rise in saving with price level increases in the $1 / 1955$ to III/1974 period. Using Wachtel's model with a different measure of inflation uncertainty yields a long-run response of saving to inflation uncertainty that is positive but statistically insignificant over the $1 / 1955$ IV $/ 1978$ sample period. However, the composition of household assets - the forms of saving - is altered

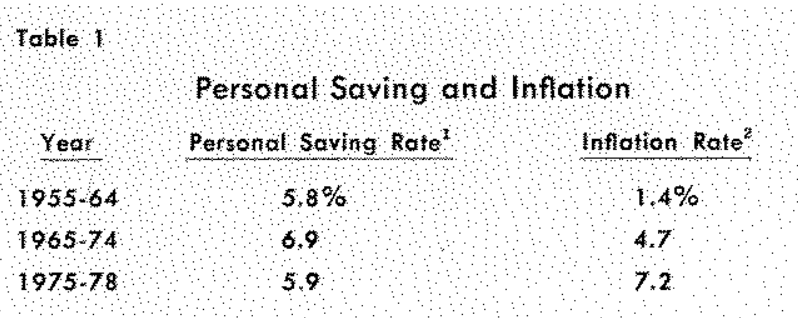

Petsonal saving/doposable petsonal income avetage of annast rates. ${ }^{2}$ Ammat rate af ehange in Consumer Price Index

SOURCE: Survey of Current Busness.

by changes in the rate of inflation. These results are consistent with traditional economic theory which indicates that inflation has no significant impact on saving in the long run except, under certain circumstances, to produce readjustment in the components of household wealth.

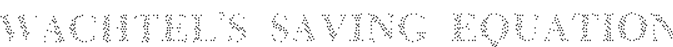

Wachtel assumed that the long-run effect of inflation on saving resulted from uncertainty created by higher and more variable inflation rates. ${ }^{2}$ Because households are unable to forecast prices accurately,

\footnotetext{
-Some recent studies suggest that countries with higher average inflation rates experience more variation in the rate of inflation and that the variability of inflation contributes to the welfare costs of inflation. See A. Okun, "The Mirage of Steady Inflation," Brookints Papers on Economic Activity (2:1971), pp. 485-98, D. If. Logue, and T. D. Willet, "A Note on the Relation between the Rate and Variability of Inflation," Econonica (May 1976) pp. 151-58, and E. Foster, "The Variability of Inflation," Review of Economics and Statistics, (August 1978), pp. 346-50.
} 


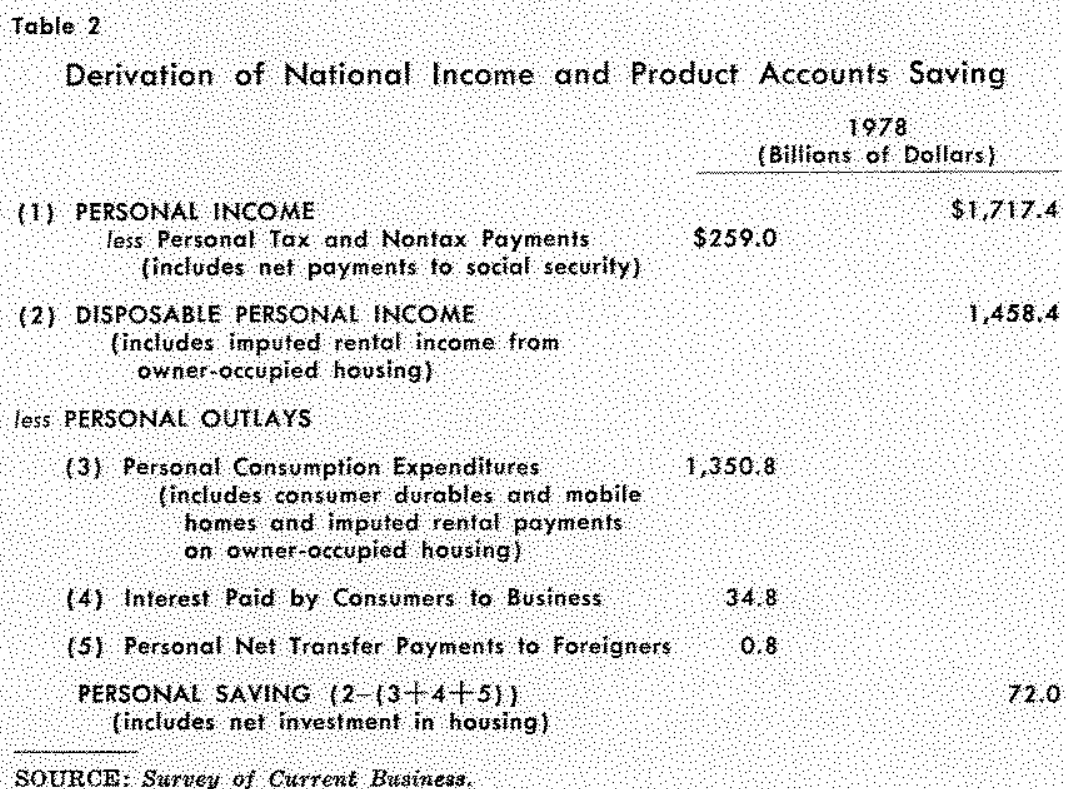

(4) Interest Paid by Consunters to Business

(5) Personal Nel Trankfer Payments to foreigners

DERSONAL SAMING $(2,3+4+5)$ (includes net investment to housing)

SOURCE surrey of Current Bitsiness

14584

cient) is not readily obtainable from the reduced-form equation. ${ }^{4}$ Nevertheless, the long-run effect of inflation uncertainty can be calculated from the coeffcient on the lagged variable $\mathrm{X}_{\mathrm{t}-1}$, where the long-run effect of uncertainty $\left(\phi_{\mathrm{x}}\right)$ equals $A_{5} /\left(1-A_{1}\right)$.

Wachtel estimated equation (3) using both National Income and Product $\mathrm{Ac}^{-}$ counts (NIA) and flow of funds (FOF) accounts saving per household, deflated by the personal consumption expenditures deflator. Disposable personal income, similarly deflated, was used as the income variable. Inflation uncertainty was measured by the average variance in households" assessment of future price increases as obtained from Survey Research Center surveys. they become uncertain about future prices and real income and, as a result, save more. Wachtel asserted that other effects of inflation on saving, such as money illusion, intertemporal substitutions, and indirect wealth and interest rate effects, have no lasting influence on saving behavior.

In order to test this hypothesis, Wachtel used the stock adjustment demand function developed earlier by Houthakker and Taylor. ${ }^{3}$ According to the speciffcations of this model, real saving per household $(q)$ is a linear function of the stock of accumulated real saving ( $s$ ), real income per household $(y)$, and inflation uncertainty $(\mathrm{X})$ :

$$
q=\alpha+\beta s+\gamma y+n_{x} x
$$

In addition, the stock of past real saving (s) is assumed to depreciate at a constant rate, $\delta$, per year.

Thus, the change in the stock of real saving (is) over a given time ( $t)$ can be represented by:

$$
\dot{s}(t)=q(t)-\delta s(t)
$$

and used to transform the structural equation into one containing only flow variables. In its reduced form, Wachtel's estimated equation was:

(3) $q_{\mathrm{t}}=\mathrm{A}_{0}+\mathrm{A}_{\mathrm{r}} \mathrm{q}_{\mathrm{t} \ldots 1}+\mathrm{A}_{2} \Delta \mathrm{y}+\mathrm{A}_{3} \mathrm{Y}_{\mathrm{t}-1}+\mathrm{A}_{4} \Delta \mathrm{X}+\mathrm{A}_{5} \mathrm{X}_{\mathrm{t}-1}$

Because the structural parameters $\beta$ and $\delta$ are overidentified, $n_{x}$ (the inflation uncertainty coeffi-

\footnotetext{
${ }^{3}$ H. S. Houthakker and Lester D. Taylor, Consumer Demand in the United States, 1929-1970: Analysis and Projeotions, (Cambridge, Mass., Harvard University Press, 1966).
}

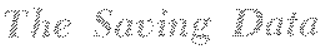

NIA saving is basically the residual after deducting current outlays for goods, services, and interest payments from current disposable personal income (Table 2). Disposable personal income consists of the after-tax receipts of households from wages and salaries, interest income, rent, dividends, and net transfer payments. Capital gains are not included. The rental valtue of owner-occupied housing is imputed and added to both personal disposable income and personal consumption expenditures. Since purchases of new housing are excluded from personal consumption expenditures, net investment in housing by households is included as a component of personal saving. Nonconsumed income, held in the form of currency, demand deposits, bonds, stocks, or pension funds, is incorporated into net financial investment. Thus, the major assets into which NIA saving flows are net housing investment and net financial investment.

The measure of household saving in the FOF accounts is also a residual, in this case, from the measured transactions among all other sectors of the economy (Table 3 ). In addition to net financial investment and net housing investment, FOF household saving includes capital gains dividends, additions to government pension funds, and net durable goods investment.

fTwo distinct values for $\beta$ and $\delta$ are generated from the reduced-form coefficients. For a technique to deal with this problem, see Ibid., pp. 21-25. 
FOF saving during the post-war period has been consistently higher than NIA saving even after adjustments for these compositional differences. Measurement errors in both series account for some portion of the discrepancy. In addition, capital gains from the sale of real estate and other durable assets (art and antiques, for example) to the business sector may add to the observed difference in the two measures. These transactions would amplify the discrepancy during periods of rising infiation.

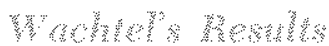

Wachtel obtained a significant positive response to inflation uncertainty for real NIA saving per household over the sample period, I/1955-III/1974. He found that a 1 percent rise (fall) in inflation uncertainty resulted in a $\$ 69$ increase (decrease) per household in real NIA saving. The inflation uncertainty coefficients in the reduced-form equation, however, were statistically insignificant using the similarly-deflated FOF saving data.

When FOF saving was disaggregated into its components - net increases in financial assets, net increases in liabilities, and net increases in tangible assets (mainly housing and durable goods) Wachtel discovered that increased uncertainty about inflation reduced net increases in liabilities and tangible assets. The reduced-form coefficients on inflation uncertainty for net increases in financial assets were negative, but statistically insignificant. Inflation uncertainty had a positive and significant effect, however, on net financial investment (net increases in financial assets less net increases in liabilities).

When Wachtel used actual price changes as the inflation variable, he found that inflation exerted a positive and statistically significant influence on both NIA and FOF saving. He concluded that inflation and the uncertainty it creates made households reluctant to acquire additional debt in order to purchase tangible assets. As a result, real saving per household rose.

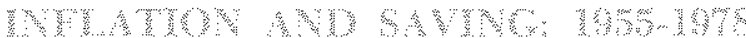

In an inflationary economy, uncertainty about future prices and real income results from the unexpected variation of prices around the generally anticipated rate of inflation. Thus, in this analysis, the uncertainty variable is approximated by using an estimate of unanticipated changes in the rate of inflation. Wachtel's equation was respecified to include measures of unanticipated $(X)$ and anticipated $(Z)$ inflation. The reduced-form equation in this analysis is:

$$
\begin{aligned}
& \mathrm{q}_{\mathrm{t}}=\mathrm{A}_{0}+\mathrm{A}_{\mathrm{z}} \mathrm{q}_{\mathrm{t}-\mathrm{z}}+\mathrm{A}_{2} \Delta \mathrm{y}+\mathrm{A}_{\mathrm{g}} \mathrm{y}_{\mathrm{t}-\mathrm{t}} \\
& +A_{t} \Delta X+A_{0} X_{t-1}+A_{0} \Delta Z+A: Z_{t-1}
\end{aligned}
$$

The coefficients on anticipated inflation $(Z)$ and on the estimated long-run effect $\left(\phi_{z}\right)$ are not expected to be statistically different from zero. This result is 


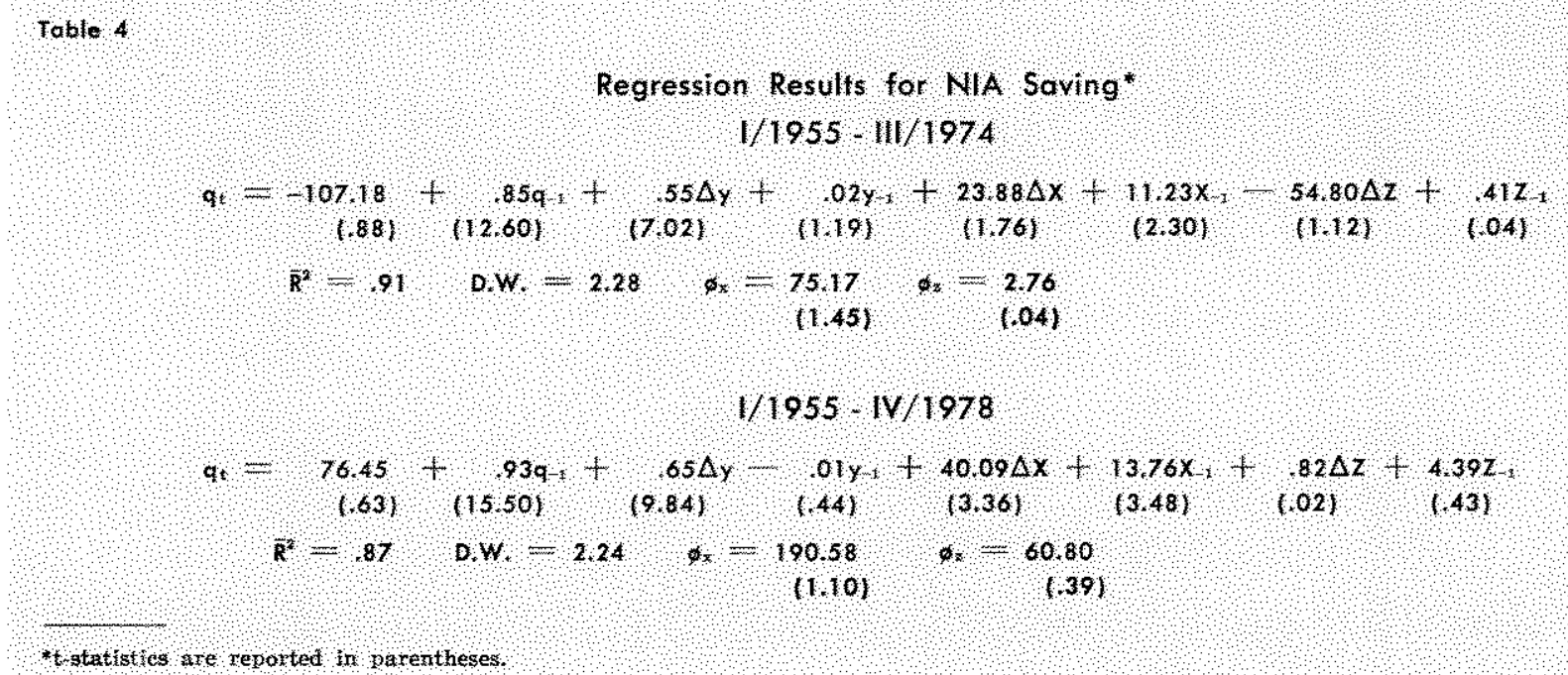

consistent with the explanation that only unanticipated inflation produces the uncertainty effect obtained by Wachtel. Furthermore, economic theory suggests that fully anticipated inflation has no lasting effect on saving behavior. Thus, unanticipated inflation $(X)$ is expected to be the only source of a positive long-run relationship between household saving and inflation. ${ }^{B}$

Since empirical evidence has shown that there is a direct relationship between lagged money growth and the fundamental rate of inflation, a 20 -quarter rate of change in the narrowly-defined money supply, M1, was initially used as a proxy for anticipated inflation. ${ }^{7}$ The difference between a four-quarter rate of change in the Consumer Price Index (CPI), a wellpublicized indicator of price change, and the money supply variable above was used to measure unanticipated inflation. All other data used to estimate equation (4) are the same as those previously used in Wachtel's study.

The equation was estimated over two sample periods: I/1955-III/1974 (the period used by Wach-

iA wealth loss contd result even with fully anticipated inflation because of the increased costs of using noney as a medium of exchange and a store of value. This effect on reat wealth conld have an impact on saving and consumption. For a discussion of the costs of anticipated intlation, see John A. Tatom, "The Welfare Costs of Inflation," this Review (Novenber 1976 ), pp. 9-22.

the positive relationship between manticipated inflation and saving is supported by the results of sereral studies. See, for example, $[$. Thomas juster and Panl Wachtel, "Inflation and the Consmer, Brooknes Papers on Economic Activity (1:1972), pp. $71-121$ and Joseph Bisignano, "1he Effect of Inflation on Savings Behavior, "Federal Reserve Babk of San Wraneiso Economic Recicw (December 1975), pp. 22-26.

TSee Denis S. Kamosky, "The Link Between Money and Prices - 19-1-66," this Review (June 1978), pp. 17-23. tel) and I/1955-IV/1978. A significantly different effect of unanticipated inflation on saving behavior before and after III/1974 would suggest that the household saving response to inflation had, in fact, changed.

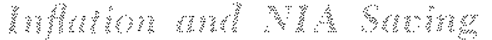

Consistent with the analysis above, anticipated inflation $(Z)$ and its long-run effect $\left(\phi_{n}\right)$ were found to have no significant impact on saving as measured in the NIA in either sample period (Table 4). Furthermore, the lagged variable of unanticipated inflation had significant positive effects on NIA saving in both periods.

When the long-run effect of unanticipated inflation $\left(\phi_{x}\right)$ is examined for the $1955-74$ period, a 1 percent rise (fall) in the rate of unanticipated inflation produced a $\$ 75$ rise (fall) in real saving per household. Over the longer sample period, this effect becomes more than twice as great: A 1 percent rise (fall) in the rate of manticipated inflation resulted in about a $\$ 192$ rise (fall) in real saving per household. In neither sample period, however, twas the long-run effect significantly different from sero at the 95 percent level of confudence.

To determine whether these findings depend upon the disaggregation of inflation into anticipated and unanticipated price changes, the saving relationship was reestimated using lagged and first differences of the actual rate of inflation, measured by a four-quarter rate of change in the CPI. The initial results prevailed: The reduced-form coefficients showed a sig- 


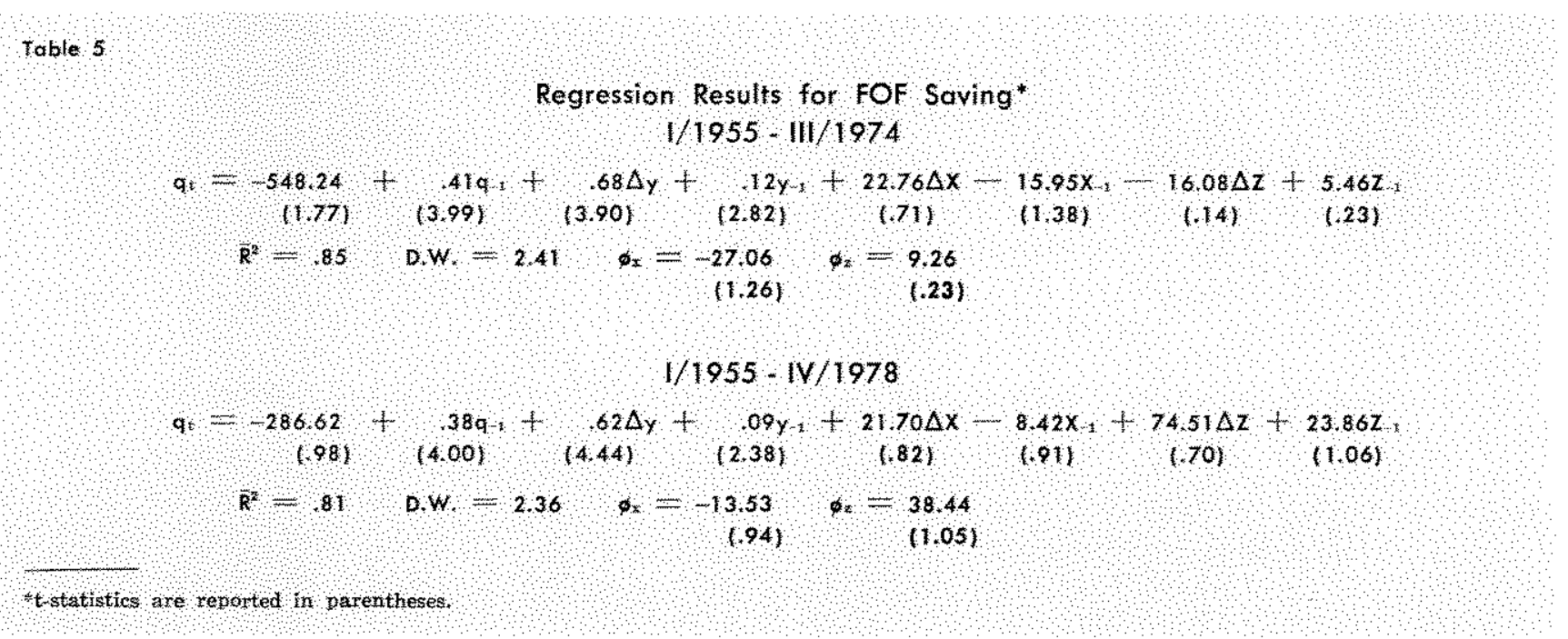

nificant positive relationship between saving and inflation, but this relationship was statistically insignificant in the long run. In summary, the existence of a significant long-run positive effect of inflation on NIA saving is not supported by the results whether a measure of inflation uncertainty or the actual inflation rate is used.

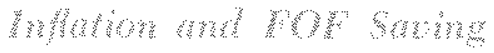

When using FOF saving, Wachtel obtained a positive effect of inflation on saving only when the actual inflation rate was substituted for his measure of inflation uncertainty. The analysis of FOF data in this study, however, reveals no such relationship. Furthermore, neither unanticipated inflation nor anticipated inflation have a significant impact on FOF saving in either sample period (Table 5). Wachtel's results showing a positive effect of actual inflation on FOF saving may be due to the estimates of depreciation of tangible assets used in his study. When Wachtel published his results, the revised estimates that are incorporated in the FOF data used in this update were not available.

Although FOF saving is not significantly affected by either inflation or inflation uncertainty, its components could be altered by adjustments across var lous household asset categories. Adjustments that reduce purchases of durable goods relative to other assets would appear as increased NIA saving with rising inflation. This occurs because durable goods purchases are classified as consumption expenditures in the NIA.

To investigate this aspect of the impact of inflation, the saving model was estimated using, as dependent variables, the three components of FOF saving: net acquisitions of financial assets, net increases in financial liabilities, and net investment in tangible assets. Tangible asset acquisitions were disaggregated into net housing and net durable goods investment.

As indicated in Table 6, the reduced-form coeffin cient on the lagged variable for unanticipated inflation is statistically significant and negative in the net durable goods investment equation over both sample periods. The long-run effect, which is not statistically significant from 1955-74, is significant in the longer sample period. The estimate of the long-run effect suggests that an increase (decrease) of 1 percent in the rate of unanticipated inflation induced a reduction (expansion) in real net durable goods investment of $\$ 45$ per household in the 1955-78 sample period. This result is consistent with a rise in NIA saving in response to a rise in unanticipated inflation.

Net housing investment appears to be strongly affected by both anticipated and unanticipated inflation in the reduced-form equation. The long-run effects of anticipated and unanticipated inflation on housing investment, however, are not statistically significant in either sample period.

When net durable goods and housing investment are aggregated into net increases in tangible assets, a significant long-run relationship with both anticipated and manticipated inflation is obtained for the 1955-74 sample period. A 1 percent increase (decrease) in the rate of unanticipated inflation produces a $\$ 63$ per household decrease (increase) in real tangible asset acquisitions. At the same time, the effect of anticipated inflation on saving is almost twice as strong, but positive: A 1 percent rise (decline) in the 
rate of anticipated inflation produces a $\$ 107$ per household rise (decline) in real net tangible asset investments.

Over the longer sample period, the positive effect of anticipated inflation on household investment in tangible assets dissipates, ${ }^{8}$ Only unanticipated inflation continues to exert an influence on net tangible asset investment that is statism tically significant in the long run. In the period, I/1955 to IV/1978, a decline (increase) in the rate of unanticipated inflation by 1 percent induced a rise (decrease) in net purchases of tangible assets of $\$ 102$ per household, nearly double the impact of the I/1955 to III/1974 period.

As separate components, net increase in financial assets and liabilities generally are not affected by anticipated or unanticipated inflation (Table 7 ). Neither the reduced-form results nor the long-run relationship between the inflation variables and the financial asset and liability components of FOF saving is statistically significant in either sample period. When net increases in financial assets and liabilities are combined (called net financial investment), however, a statistically significant positive long-run response to unanticipated inflation results, but only over the $1955-78$ sample period.

Assuming an anticipated rate of inflation of about 6 percent from 1974 to 1976 , these findings suggest that the decline in the rate of inflation from 11 percent in 1974 to 5.6 percent in 1976 resulted in a reduction in real net financial investment of approximately $\$ 280$ per household, or $\$ 20$ billion, and a net increase in real durable goods investment of about $\$ 243$ per household, or $\$ 17$ billion from 1975 to 1977 . Therefore, the effects of this reduction in unanticipated inflation would have contributed to the observed decline in NIA saving in that period.

\footnotetext{
8The trend growth of money - anticipated inflation - tended to stabilize around a 6 percent annal rate after 1972 , providing no further positive impetus to tangible asset acquisition. This is consistent with a me-time shift from money to goods resulting from the transition to a higher expected rate of inflation.
}

Tangible Asset Component of FOF Saving*
Net Increase in Housing Investment

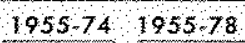
22451 $(3.04)$

161 8 (17.54) आ31,17 $-002 \quad 01$ 1071 02

(3)13)

$(48)$

002

1311

$-7,05 \quad-15,41$

11,251

(3.30)

$-4,56$

(232)

$-4.36$

(2.93)

40.01

21,53

$(2,10)$

(1.22)

1517

$(337)$

5.86

11501

95

95

1,36

$3508 \quad 32298$

(1.50)

(1,03)

18.52

434.07

$(1,72)$

(15)

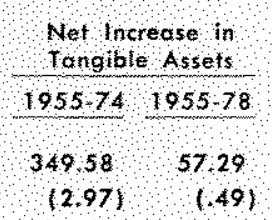

(.52) $(2.27)$

$69 \quad \square 67 \quad 2 \quad 83 \quad \square \quad 81$

$(8.80) \quad(7.86) \quad(10.57) \quad(1274)$

$19 \quad 12 \quad 17 \quad 12$

$(3,30) \quad(284) \quad$ (2. $\$ 3)$ (2.06)

$01 \quad 0003 \quad 0 \quad 03 \quad \Omega \quad 002$

$(87) \quad(2,60) \quad(1,92) \quad(16)$

$0,56 \quad 160 \quad \square \quad 499 \quad 1843$

$(05) \quad(18) \quad 3 \quad(35) \quad(137)$

$-1090 \quad-17,72 \quad \square-17 / 0 \quad-19,12$

$(2,56) \quad(5,20) \quad 3 \quad(3 / 17) \quad(4,27)$

$55.41 \quad 20017 \quad 0 \quad 83.50 \quad 225.95$

$(1,53) \quad(.64) \quad(1,85) \quad$ (150)

$1065 \quad 3,18 \quad 29,15 \quad 1311$

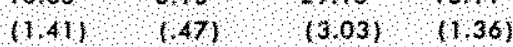

$912 \quad 380 \quad \square \quad 889 \quad \square \quad 88$

$108 \quad 202 \quad 3 \quad 153 \quad 1.63$

$3460 \quad 44.89$

$(1,77) \quad(2,86)$

338180.06

1134

$(48)$

$6333 \quad 102,36$

$(198)(1.96)$

$107,96,70,18$

$(2,17)(1,16$

* totatusetes are reported in parentheses

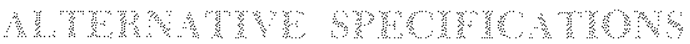

Several alternative measures of anticipated and unanticipated inflation were used in reestimating equation (4). First, an anticipated inflation series was generated using forecasts of future price changes from the Livingston survey. "These semiannual forecasts were interpolated to create a quarterly data series and the difference between the expected rate of price change generated by these forecasts and the actual inflation rate was used as the measure of unanticipated inflation. Under this specification, both unanticipated and anticipated inflation showed a positive long-run effect on NIA saving in the 1955-74 sample period, which contradicts the hypothesis that anticipated inflation has no long-run effect on saving.

"J. Aivingston, "Business Outlook," The Philadelphia Record, June 1954-December 1978. 
Table 7

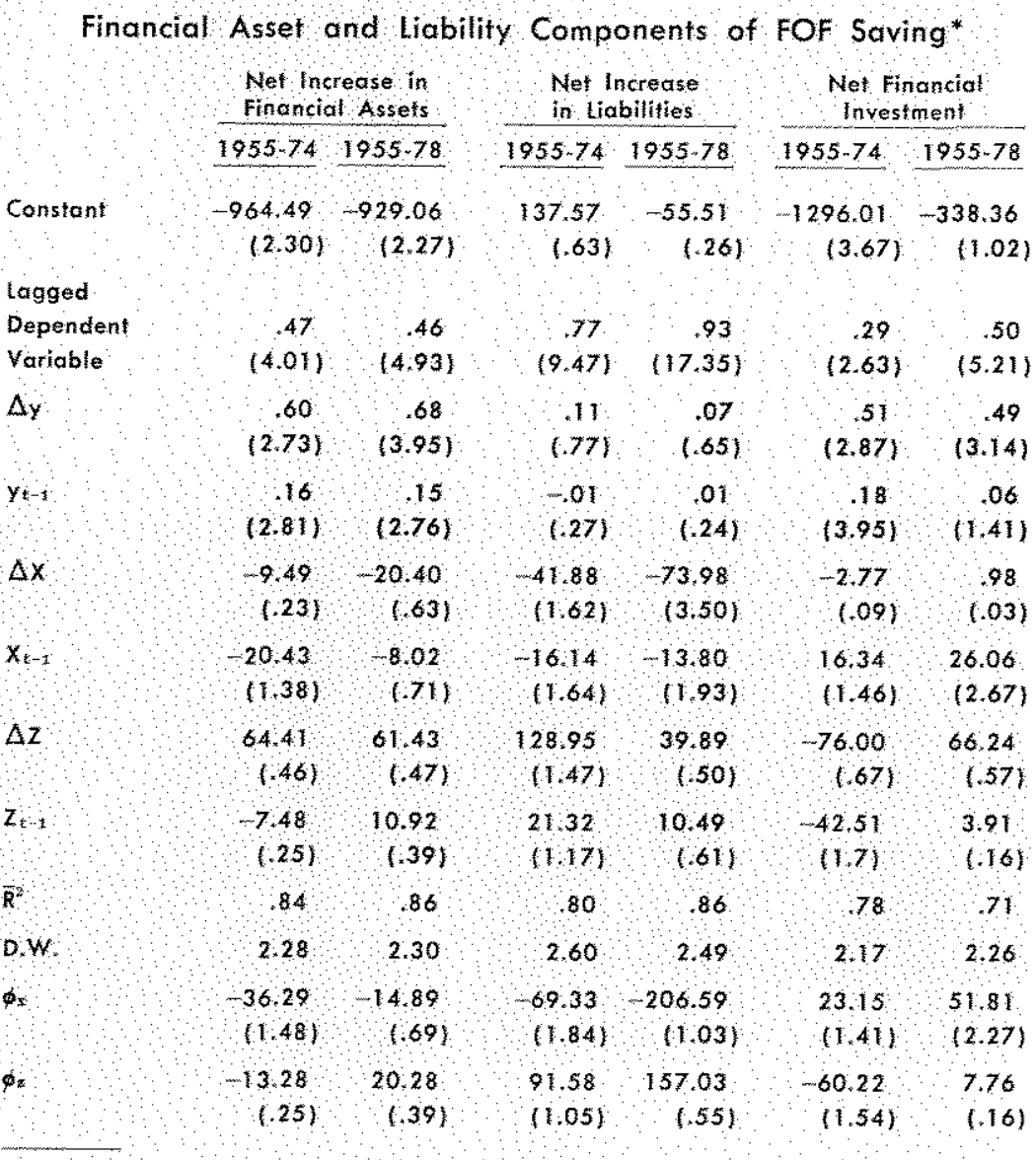

unanticipated inflation on NIA saving was statistically significant at the 90 percent level over both sample periods.

Although these alternative measures of inflation anticipations yield positive longrun relationships between inflation and NIA saving, they show no effect of inflation on FOF saving. Wachtel encountered this same dichotomy in his analysis - the results are sensitive to the saving measure used.

\section{Wrenthys}

As an update to previous work on the relationship between inflation and saving, this study finds no conclusive evidence that inflation has a positive longrun effect on saving. FOF saving, which represents net additions to household wealth, is not affected by any measure of inflation or inflationary anticipations used in the analysis. NIA saving, a narrower measure, is not affected by actual inflation nor by unanticipated inflation derived from the difference between actual prices and lagged money growth. The use of Livingston survey and Scadding data, however, produce a positive relationship between unanticipated inflation and NIA saving. Both Livingston and Scadding data are sensitive to the saving measure used.

Unanticipated inflation had a significant long-run effect on the components of saving over the 1955 . 78 sample period. Rising rates of unanticipated infation reduced durable goods investment and increased net financial investment. The observed positive relationship between inflation and NIA saving is due, in large part, to the negative effect of unanticipated infation on durable goods purchases, which are classified as consumption expenditures in the NIA.
10) John L. Scadding, "Estimating the Underlyng Inflation Rate," Federal Reserve Bank of San Francisco Economic Review (Spring 1979), pp. 7-18. 